\title{
PHOTOSYNTHETIC INOCULANTS FOR PROMOTING SEED GERMINATION AND DEVELOPMENT OF TOMATO PLANTS
}

\author{
Loredana-Mirela Sfîrloagă ${ }^{1}$, Mihaela Croitoru ${ }^{1^{*}}$, Aurelia Diaconu ${ }^{1}$, \\ Alina-Nicoleta Paraschiv ${ }^{1}$, Ioan Ardelean ${ }^{2}$ \\ ${ }^{1}$ Research and Development Station for Plant Growing on Sand Dăbuleni, \\ 217 Petre Banița street. 207220 .Dolj County, Romania \\ ${ }^{2}$ Institute of Biology Bucharest. Romanian Academy, 296, Splaiul Independenței, \\ 060031 Bucharest. P.O. Box 56-53, Romania
}

\section{Current Trends in}

Natural Sciences

\begin{abstract}
Microalgae and cyanobacteria are a potentially sustainable alternative for the improvement and protection of agricultural crops. Mineral fertilizers raise environmental and health issues. and current agricultural practices depend to a large extent on the application of fertilizers and pesticides.

In this study. we examined the effect of cyanobacteria and microalgae on tomato seed germination. seedling growth. green and dry biomass. gas exchange from leaves (plant photosynthesis and transpiration). and the chlorophyll content of leaves (chlorophyll $a . b$ and carotene). as well as on the soil respiration process.

The obtained results highlight higher values of green and dry biomass in the variants inoculated with cyanobacteria and microalgae compared to the control variant and comparable to the values obtained in the technologically fertilized variants. Tomato seedlings showed higher photosynthesis values compared to the control and compared to the technologically fertilized variant in the soil of the pea plot $\left(7.06 \mu \mathrm{mol} \mathrm{CO} / \mathrm{Cm}^{2} / \mathrm{s}\right.$ compared to $6.33 \mu \mathrm{mol} \mathrm{CO} / \mathrm{m}^{2} / \mathrm{s}$ in the control variant and $7.06 \mu \mathrm{mol} \mathrm{CO}_{2} / \mathrm{m}^{2} / \mathrm{s}$ in the technologically fertilized version). And in the case of the soil in the museum plot. the values of photosynthesis in the version with the inoculum of cyanobacteria and microalgae were statistically assured compared to the control.
\end{abstract}

Keywords: biofertilizers, germination, the inoculum.

\section{INTRODUCTION}

Society faces a challenge, not only to increase agricultural production amid threatening global climate change, to reduce crops in many parts of the world, but also to develop innovative technologies that increase agricultural yields, minimize incomes and discourage further environmental pollution (Tilman et al., 2002; Foley et al., 2011).

Excessive use of synthetic agrochemicals has led to massive ecological degradation worldwide, leading to dead ocean areas, eutrophication, soil infertility and biodiversity loss (Köhler \& Triebskorn, 2013; Chagnon et al., 2014; Hallmann et al., 2014; Van der Sluijs et al., 2014). 
The use of microalgae and cyanobacteria as biofertilizers offers a possible solution. The use of algae in agriculture dates back thousands of years (Dmytryk \& Chojnacka, 2018; Górka et al., 2018): for example, in coastal areas of Europe, farmers applied algae harvested near the shore in their crops, both directly and indirectly, after composting, observing positive effects in soil fertilization. From this period, algae biomass was widely used in agriculture, but in the twentieth century, products obtained from algae extracts attracted the attention of farmers around the world (Dmytryk \& Chojnacka, 2018).

In search of more sustainable and environmentally friendly solutions to improve agricultural productivity, researchers have focused on organic products. with microalgae and cyanobacteria emerging as a valuable resource for crop production and protection due to their potential for biofertilization and biostimulation (Pathak et al., 2018; Chaiaese et al., 2018; Dmytryk \& Chojnacka, 2018; Pan et al., 2019; Gorka et al., 2018).

Biofertilizers are considered to be an ecological, cost-effective and sustainable alternative to synthetic fertilizers, because they not only increase agricultural production, but also reduce environmental pollution (Kawalekar, 2013). Biofertilizers are products that contain living microorganisms or natural compounds derived from organisms such as bacteria, fungi and algae that improve the chemical and biological properties of the soil. stimulate plant growth and restore soil fertility (Abdel-Raouf et al., 2012).

Given that microalgae and cyanobacteria contain high levels of micronutrients and macronutrients essential for plant growth, they have a potential application as biofertilizers. Several studies have established an association between higher nutrient uptake, higher biomass accumulation, and higher crop yields when incorporating microalgae biofertilizers (Shaaban, 2001; Faheed \& Abd-El Fattah, 2008).

Following studies that have investigated the effects of algae extracts on seed germination have shown faster germination and higher growth of rice seeds (Shukla \& Gupta, 1967). Other more recent studies have obtained similar results using seaweed extracts on tomato and wheat seeds, although they have also observed growth inhibition with increasing extract concentrations (Kumar \& Sahoo, 2011; Kumari et al., 2011; Hernández-Herrera et al., 2013).

Microalgae and cyanobacteria are an important source of biologically active compounds, such as phenolic compounds, polysaccharides, hormone-like substances and proteins, known for their benefits as antioxidants, plant growth promoters, among others. Moreover, living organisms, both prokaryotes (e.g., nitrogen-fixing cyanobacteria) and eukaryotes (e.g., microalgae and macroalgae / seaweeds), are widely recognized for their role in soil fertilization and plant growth stimulation (Chaiaese et al., 2018).

It has been shown that cell extracts and the growth environment of several species of microalgae contain phytohormones (gibberellins, auxins and cytokinins), which are known to play a crucial role in plant development (Tarakhovskaya et al., 2007).

In the context of the depreciation of the quality of agricultural areas, but also of their irrecoverable losses, it is necessary to establish new strategies for preserving agricultural land. Among these, the 
most important should present the following research directions: evaluation of the quality of soil biological resources and the state of agricultural land degradation, evaluation of anthropogenic action on soil fertility assessed with the help of biological indicators. establishment of improvement technologies on preservation of soil fertility, etc. (Agud, 2012).

The use of microalgae / cyanobacteria biomass (or their extracts) can be a sustainable and viable alternative to chemical fertilizers, pesticides and growth stimulants. In addition, the use of these biologically based substances / organisms is an important step towards improving agricultural productivity, which is essential for meeting the growing food needs of the world's population.

The aim of this paper is to continue our research on the use of biocrust formation with selected consortia of cyanobacteria and green micralgae (Sfîrloagă et al., 2020) to stimulate tomate growth and to introduce for the first time in our scientific work, following pioneering national work (Eliade et al., 1975) in agreement with international trends (Sandor, 2010) the quantification of endogenous soil respiration.

\section{MATERIALS AND METHODS}

Previous research has shown that cyanobacteria and microalgae have been used as biological fertilizer, and may be an increasingly viable alternative to the problems caused by climate change (Aladhali, 2021).

Aladhali, 2021 showed that cyanobacteria and microalgae have contributed to the accumulation of nutrients and organic matter in the soil, but at the same time, help to fix them in the plant.

At RDSPCS Dăbuleni, a study was initiated on the influence of the application of cyanobacteria and microalgae in the soil improvement process, as well as their role in the germination of Romec $554 j$ tomato seeds.

The experience was bifactorial, with the following factors:

Factor A - soil type;

A1- soil from the pea plot (improved soil type);

A 2- soil from the museum plot (type of sandy soil in natural state).

Factor B- Treatments performed:

V1- Soil from the pea plot Control;

V2 - Soil from the pea plot fertilized according to technology $\left(\mathrm{N}_{80} \mathrm{P}_{150} \mathrm{~K}_{100}\right)$;

V3- Soil from the pea plot treated with the inoculum of cyanobacteria and microalgae;

V4- Soil from the museum plot Control;

V5- Soil from the museum plot fertilized according to technology ( $\left.\mathrm{N}_{80} \mathrm{P}_{150} \mathrm{~K}_{100}\right)$;

V6- Soil from the museum treated with the inoculum of cyanobacteria and microalgae.

The experiment was placed inside the Biochemistry Laboratory. in rectangular plastic containers. with a volume of 41 , which were filled with the 2 types of soil and the treatments from the established variants were performed. Tomatoes of the Romec $554 j$ variety were sown in pots.

During the period of seedling growth, the following observations and determinations were made:

- for plants - biometric measurements on plants (seedling length in $\mathrm{cm}$ ); 
- determination of wet biomass by weighing on the KERN type electronic balance;

- determination of dry biomass by gravimetric method (drying at $105{ }^{\circ} \mathrm{C}$ ), using a BINDER type thermoregulation oven;

- in leaves - determination of chlorophyll $\mathrm{a}+\mathrm{b}$ and carotenoid pigments by spectrophotometric method using a Metertek SP-830 Spectrophotometer;

- determination of the physiological processes of photosynthesis and perspiration with the portable device $L C$ pro $S D$;

Endogenous soil respiration measurement was done following (Gupta \& Singh.1977). After the titration, it is possible to calculate the released $\mathrm{CO}_{2}$ with the next equation:

$$
R C O 2=2.2(V b-V p) / m_{s} w_{s d}
$$

Where:

- $\mathrm{RCO}_{2}$ is the rate of $\mathrm{CO}_{2}$ evolution on a dry soil (mgCO2 $\left.\mathrm{g}-1\right)$;

- $\mathrm{Vb}$ is the volume of $\mathrm{HCl}$ consumed in the control $(\mathrm{ml})$;

- $\mathrm{Vp}$ is the volume of $\mathrm{HCl}$ consumed in the test sample $(\mathrm{ml})$;

- $\mathrm{ms}$ is the mass of the soil sample $(\mathrm{g})$;

- 2.2 is a factor ( $1 \mathrm{ml}$ of 0.1 molar $\mathrm{HCl}$ corresponds to $2.2 \mathrm{mg}$ of $\left.\mathrm{CO}_{2}\right)(\mathrm{mg} \mathrm{ml}-1)$.

\section{RESULTS AND DISCUSSIONS}

Microalgae and cyanobacteria are an important source of a wide variety of bioactive compounds that can regulate several plant response mechanisms: improving soil quality and plant nutrition protecting plants against biotic and abiotic factors and stimulating growth.

The biocrust of microorganisms has a unique potential to increase productivity in a variety of agricultural and ecological situations and plays an important role in the development of soil fertility, thus increasing yield. The use of cyanobacteria and microalgae as a soil additive has been shown to significantly improve germination, nitrate reduction potential, root volume, chlorophyll formation, carotenoid accumulation, plant yields, dry shoot weight and plant height (Tripathi et al., 2008 ; Lin et al., 2013; Odjadjare et al., 2017).

In the soil variants from the pea parcel, the best results regarding the green and dry biomass were obtained in the version with cyanobacteria and microalgae $(0.73 \mathrm{~g}$ respectively $0.05 \mathrm{~g})$ (Table 1$)$. In the case of the soil in the museum plot (sandy soil in natural state) the values of green and dry biomass presented statistically assured values as significant in the technologically fertilized variant ( $1.11 \mathrm{~g}$ respectively $0.10 \mathrm{~g}$ compared to the control variant $0.66 \mathrm{~g}$ respectively $0.05 \mathrm{~g}$ ).

Tomato seedlings (seedlings) showed higher values of photosynthesis compared to the control variant and the technologically fertilized variant in the soil of the pea plot $\left(7.06 \mu \mathrm{mol} \mathrm{CO}_{2} / \mathrm{m}^{2} / \mathrm{s}\right.$ compared to $6.33 \mu \mathrm{mol} \mathrm{CO}_{2} / \mathrm{m}^{2} / \mathrm{s}$ in the control variant and $5.52 \mu \mathrm{mol} \mathrm{CO}_{2} / \mathrm{m}^{2} / \mathrm{s}$ in the technologically fertilized variant). In the case of the soil in the museum plot, the values of photosynthesis in the version with the inoculum of cyanobacteria and microalgae, as well as in the technologically fertilized version were ensured statistically compared to the control version. 


\section{Current Trends in Natural Sciences}

Vol. 10, Issue 20, pp. 130-140, 2021

https://doi.org/10.47068/ctns.2021.v10i20.018

Current Trends in Natural Sciences (on-line)

The higher the vegetative mass and the more intense photosynthesis of the seedlings, the higher the transpiration values of the leaves. Between the two physiological processes a significant polynomial correlation was established $(\mathrm{r}=0.99 * *)$, the perspiration of the leaves intensifies with the increase of the photosynthesis (Figure 1).

Table 1. The influence of treatments with cyanobacteria and the inoculation of microalgae in the soil, on some physiological properties of tomato seedlings

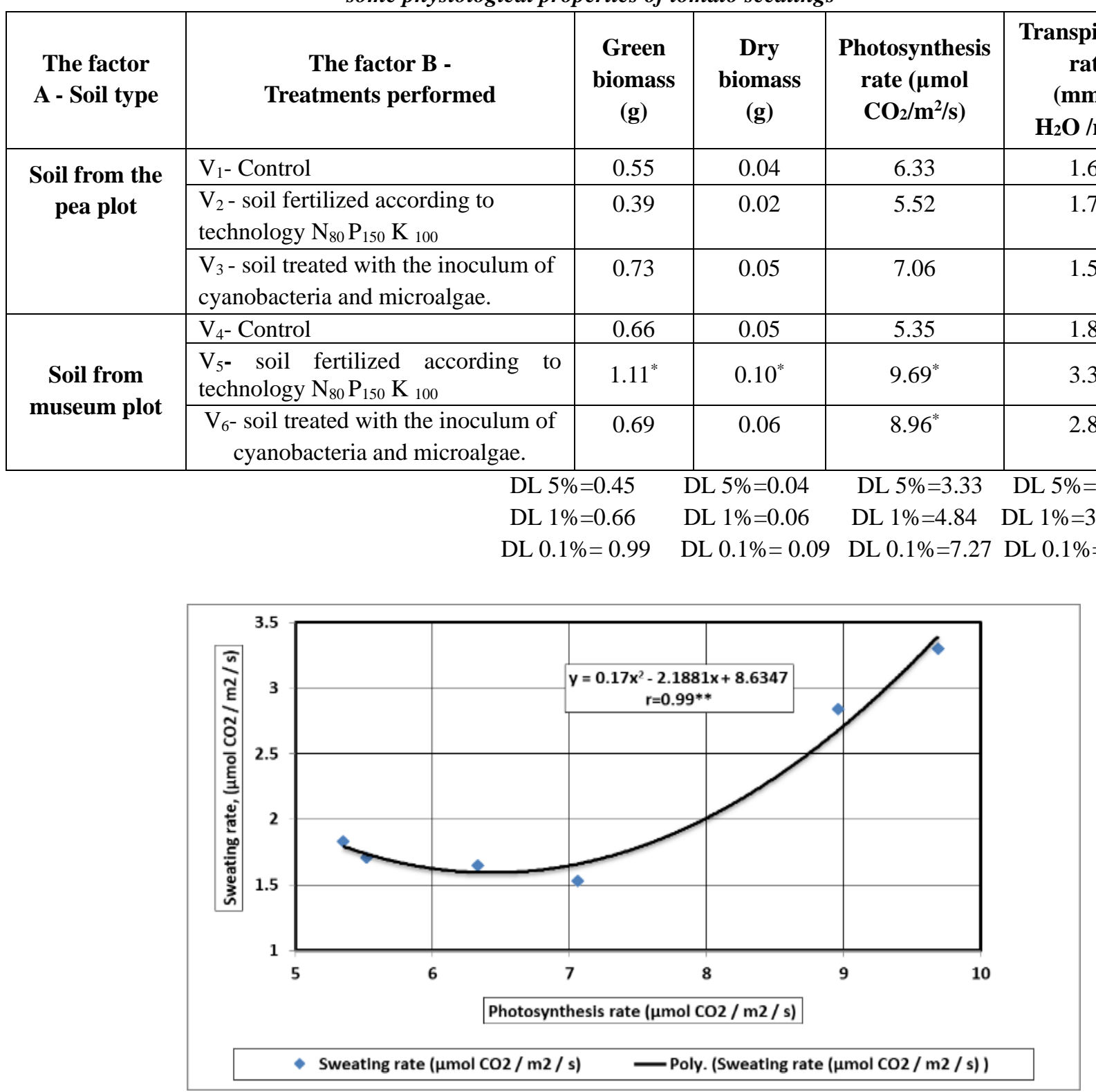

Figure 1. Correlation between the rate of photosynthesis and transpiration in the variants with the inoculum of cyanobacteria and microalgae on the two soil types 


\section{Current Trends in Natural Sciences}

Vol. 10, Issue 20, pp. 130-140, 2021

https://doi.org/10.47068/ctns.2021.v10i20.018

Current Trends in Natural Sciences (on-line)

Also a negative polynomial correlation was established between the amount of chlorophyll and the intensity of photosynthesis in the leaves, photosynthesis increases with the increase of the amount of chlorophyll up to values of 10.5-11 mg / $\mathrm{g}$ fresh substance (Figure 2).

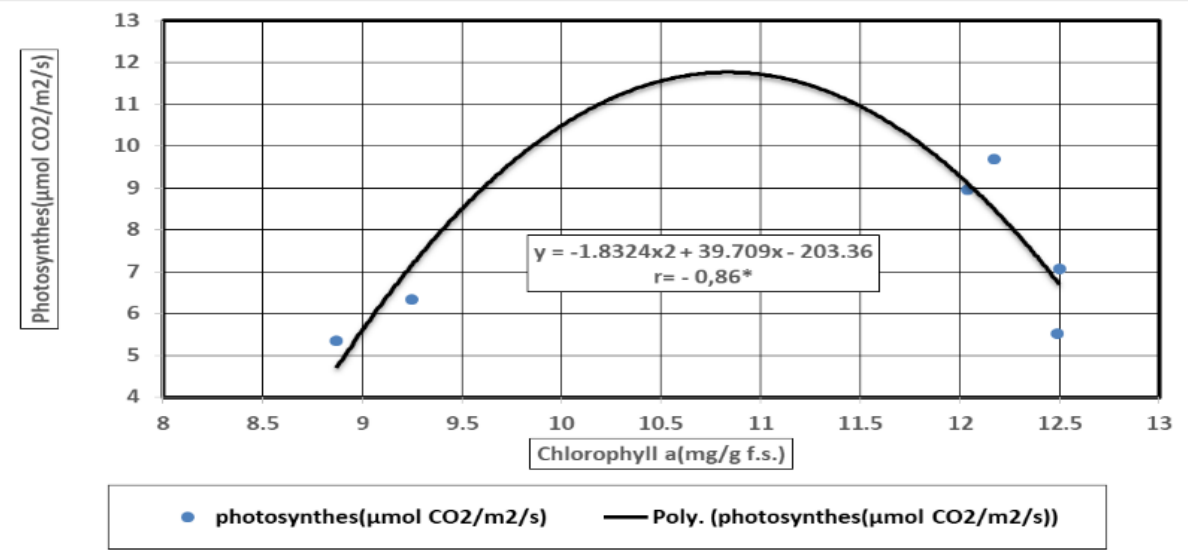

Figure 2. Correlation between the amount of chlorophyll a in the leaves and photosynthesis

Treatment of the two soil types with the inoculation of cyanobacteria and algae positively influenced the accumulation of chlorophyll $\mathrm{a}+\mathrm{b}$ and carotene in the leaves of tomato seedlings (Table 2). The highest values were determined in the variants with soil from the technologically fertilized pea plot and with cyanobacteria, and in the case of the soil from the museum plot in the technologically fertilized version, followed by the variant with inoculum with cyanobacteria and microalgae.

Table 2.The influence of inoculum of cyanobacteria and microalgae in the soil. on the content of chlorophyll $a+b$ and carotene in the leaves of tomato seedlings

\begin{tabular}{|c|c|c|c|}
\hline The factor $A$ & The factor $B$ & $\begin{array}{c}\text { Chlorophyll } \\
\mathbf{a}+\mathbf{b} \\
(\mathrm{mg} / \mathrm{g} \text { f.s } *)\end{array}$ & $\begin{array}{l}\text { Carotenoid } \\
\left(\mathrm{mg} / \mathrm{g} \text { f.s } \mathrm{s}^{*}\right)\end{array}$ \\
\hline \multirow{3}{*}{$\begin{array}{c}\text { Soil from the pea } \\
\text { plot }\end{array}$} & $\mathrm{V}_{1}$ - Control & 20.63 & 6.41 \\
\hline & $\begin{array}{l}\mathrm{V}_{2} \text { - soil fertilized according to } \\
\text { technology } \mathrm{N}_{80} \mathrm{P}_{150} \mathrm{~K}_{100}\end{array}$ & 26.25 & 11.54 \\
\hline & $\begin{array}{l}\mathrm{V}_{3} \text { - soil treated with the inoculum of } \\
\text { cyanobacteria and microalgae. }\end{array}$ & 26.20 & 11.92 \\
\hline \multirow{3}{*}{$\begin{array}{c}\text { Soil from } \\
\text { museum plot }\end{array}$} & $\mathrm{V}_{4^{-}}$Control & 17.62 & 8.10 \\
\hline & $\begin{array}{l}\mathrm{V}_{5^{-}} \text {soil fertilized according to } \\
\text { technology } \mathrm{N}_{80} \mathrm{P}_{150} \mathrm{~K}_{100}\end{array}$ & 26.93 & 11.88 \\
\hline & $\begin{array}{l}\mathrm{V}_{6 \text { - }} \text { soil treated with the inoculum of } \\
\text { cyanobacteria and microalgae. }\end{array}$ & 25.11 & 11.37 \\
\hline
\end{tabular}

f.s*- fresh substance 


\section{Current Trends in Natural Sciences}

Vol. 10, Issue 20, pp. 130-140, 2021

https://doi.org/10.47068/ctns.2021.v10i20.018

Current Trends in Natural Sciences (on-line)

The amount of carotene in the leaves of tomato seedlings accumulates with increasing amount of chlorophyll $\mathrm{a}+\mathrm{b}$, after a polynomial correlation, with a significant correlation factor $(\mathrm{r}=0.94 * *)$ (Figure 3).

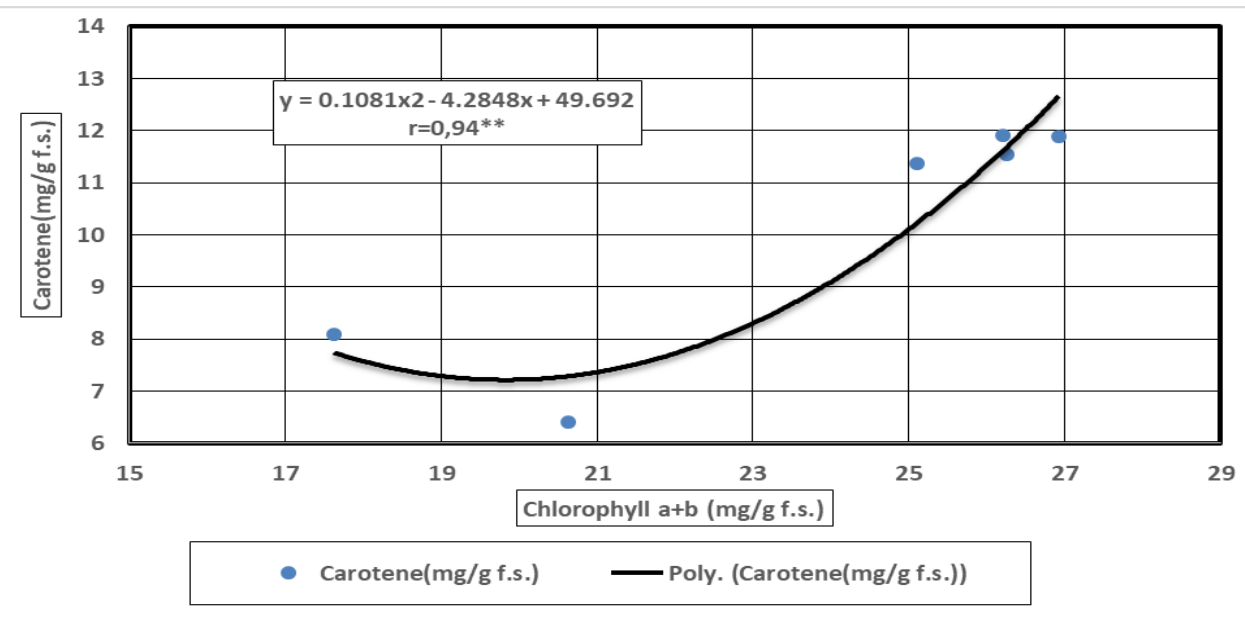

Figure 3. Correlation between the amount of chlorophyll $a+b$ in the leaves and the amount of carotene

In the next figure (Figure 4) there are presented the time evolution of endogenous soil aerobic repiration in the six variants of soil treatment (sea materials and methods).

Endogenous soil respiration is influenced by the biocrust at short term levels 10 days. There is a decrease in the endogenous respiration in time, probably as an effect of substrate consumption in time.

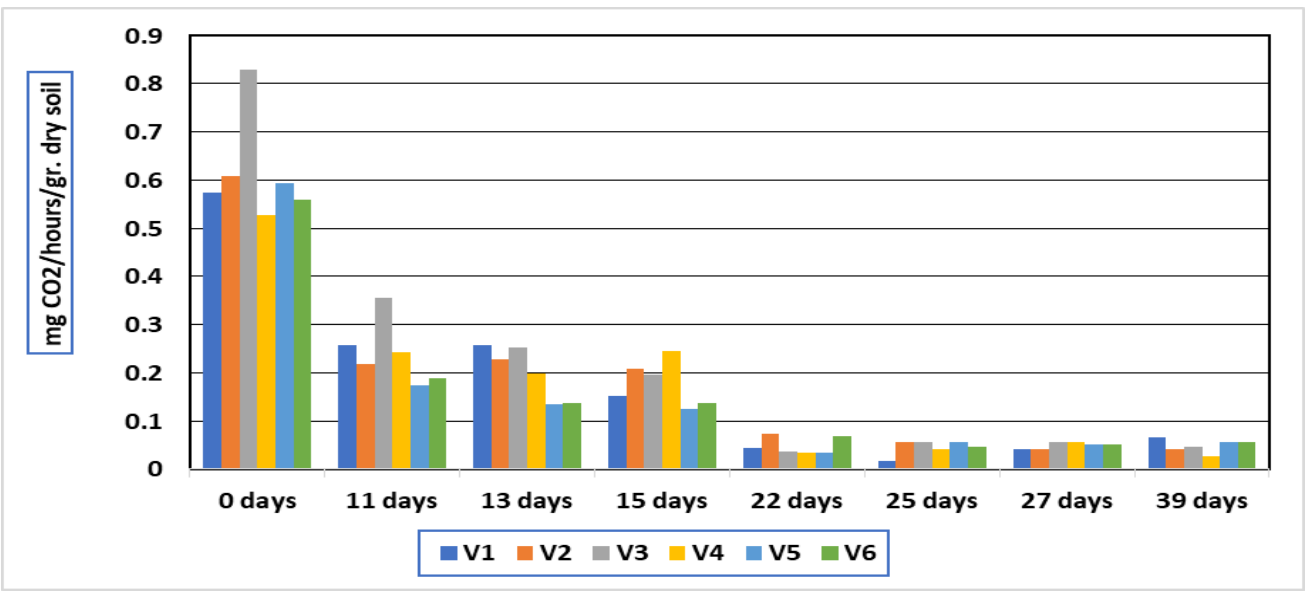

Figure 4. Soil respiration expressed in $\mathrm{mg} \mathrm{CO}_{2} / 24$ hours/g dry soil

At the beginning in variant with soil treated with the inoculum of cyanobacteria and microalgae, in soil from the pea plot, has a higher respiration activity, probably because of the contribution of 


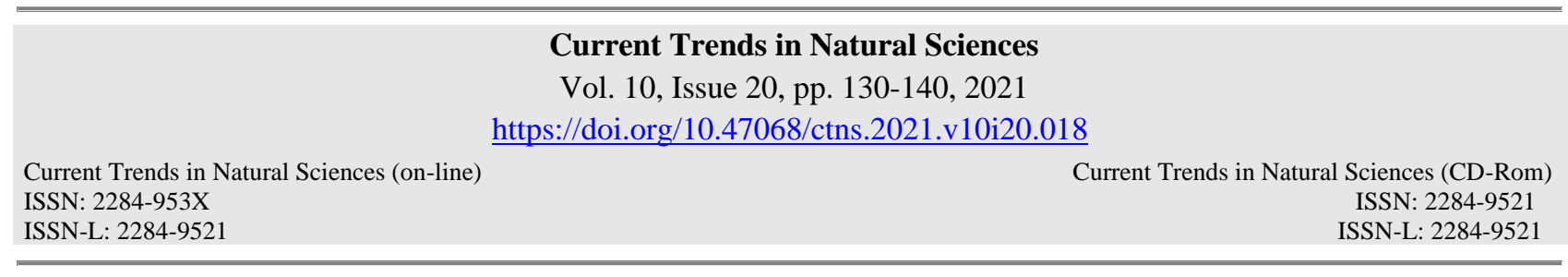

phototrophic microorganisms to organic carbon budget in the soil, more pronounced in this variant than in soil treated with the inoculum of cyanobacteria and microalgae, in soil from museum plot.

The soil harvested from the pea plot has a higher amount of organic matter, which comes from the biomass of the microbial communities in the soil, as well as from the roots of the plants (peas has a pivoting root which penetrates $30-90 \mathrm{~cm}$, well branched and which develops nodules populated by bacteria - Rhizobium leguminosarum, atmospheric nitrogen fixers). The amount of activated carbon, which can serve as a source of food and energy readily available for the microbial flora of the soil, was higher in the variant, with the inoculation of cyanobacteria and microalgae. By determining soil respiration, which is an indicator of carbon dioxide $\left(\mathrm{CO}_{2}\right)$ released as a result of the decomposition of organic matter by soil microorganisms and root respiration, the role of the addition of the cyanobacterial and microalgae inoculum in the accumulation of organic carbon in degraded soils such as sandy soils.

\section{CONCLUSIONS}

The values of green and dry biomass from the variants inoculated with cyanobacteria and microalgae were higher compared to the control variant and comparable to the values obtained in the technologically fertilized variants, regardless of the type of soil studied.

In the case of the soil in the museum plot, the values of photosynthesis in the variant with the inoculum of cyanobacteria and microalgae were statistically ensured compared to the control variant.

The photosynthesis of the leaves increased significantly with the increase of the amount of chlorophyll in the leaves to its values of $10.5-11 \mathrm{mg} / \mathrm{g}$ fresh substance.

The treatment of the two soil types with the inoculation of cyanobacteria and algae positively influenced the accumulation of chlorophyll $\mathrm{a}+\mathrm{b}$ and carotene in the leaves of tomato seedlings. The highest values were determined in the variants with soil from the technologically fertilized pea plot and with cyanobacteria, and in the case of the soil from the museum plot in the technologically fertilized version, followed by the variant with inoculum with cyanobacteria and microalgae. Endogenous soil respiration is influenced by the biocrust at short term levels 10 days.

There is a decrease in the endogenous respiration in time, probably as an effect of substrate consumption in time.

At the beginning in variant with soil treated with the inoculum of cyanobacteria and microalgae, in soil from the pea plot, has a higher respiration activity, probably because of the contribution of phototrophic microorganisms to organic carbon budget in the soil, more pronounced in this variant than in soil treated with the inoculum of cyanobacteria and microalgae, in soil from museum plot.

By determining soil respiration, which is an indicator of carbon dioxide $\left(\mathrm{CO}_{2}\right)$ released as a result of the decomposition of organic matter by soil microorganisms and root respiration, the role of the addition of the cyanobacterial and microalgae inoculum in the accumulation of organic carbon in degraded soils such as sandy soils. 


\section{Current Trends in Natural Sciences}

Vol. 10, Issue 20, pp. 130-140, 2021

https://doi.org/10.47068/ctns.2021.v10i20.018

Current Trends in Natural Sciences (on-line)

ISSN: 2284-953X

Current Trends in Natural Sciences (CD-Rom)

ISSN: 2284-9521

ISSN-L: 2284-9521

ISSN-L: 2284-9521

\section{REFERENCES}

Abdel-Raouf. N., Al-Homaidan. A.A., Ibraheem. I.B.M. (2012). Agricultural importance of algae. Afr J Biotechnol 11, $11648-11658$

Agud. E., (2012). Aspects and Principles of Improvement of a Urban Ecosystem. Analele Universităţii din Oradea. Fascicula Protecția Mediului. Edit. Universitatea din Oradea. 19, 607 - 615.

Aladhali. Z., (2021). Review on what state of the art in fertilizing with algae and what are the scientific gaps needed to be investigated. Academia Letters. Article 2056. https://doi.org/10.20935/AL2056.

Chagnon. M., Kreutzweiser. D., Mitchell. E.A.D., Morrissey. C.A., Noome. D.A., Van Der Sluijs. J.P., (2014). Risks of large-scale use of systemic insecticides to ecosystem functioning and services. Environ Sci Pollut Res. doi:10.1007/s11356-014-3277-x.

Chiaiese. P., Corrado. G., Colla. G., Kyriacou. M.C., Rouphael. Y., (2018). Renewable Sources of Plant Biostimulation: Microalgae as a Sustainable Means to Improve Crop Performance. Front. Plant Sci.. 9.1782

Dincă. Z.,Vidican. R., Rotar I., Șandor M., (2014). Study of the soil respiration and evaporation of ten soybean varieties in the field conditions from SCDA Turda. Bulletin USAMV series Agriculture 71(2). DOI 10.15835/buasvmcnagr: 10763 .

Dmytryk. A., Chojnacka. K., (2018). Algae as fertilizers. biostimulants. and regulators of plant growth. In Algae Biomass: Characteristics and Applications; Chojnacka. K.. Wieczorek. P.P.. Schroeder. G.. Michalak. I.. Eds.; Springer: Cham. Switzerland.; pp. 115-122.

Eliade. G., Ghinea L. \& Ștefanic G. (1975). Microbiologia solului. Bazele biologice ale agrotehnicii. Editura Ceres. București.

Faheed. F.A., Abd-El Fattah. Z., (2008). Effect of Chlorella vulgaris as biofertilizer on growth parameters and metabolic aspects of lettuce plant. J Agric Social Sci 4, 165-169.

Foley. A.J., Ramankutty. N., Braumanak. Cassidy. S.E., Gerber. S.J., Johnston. M., Mueller. D.N., O'connell. C., Ray. K.D., West. C.P.., Balzer. C., Bennett. M.E., Carpenter. R.S., Hill. J., Monfreda. C., Polasky. S., Rockstrom. J., Sheeban. J.. Siebert. S.. Tilman. D.. Zaks. P.D. (2011). Solutions for a cultivated planet. Nature 478, $337-342$.

Faheed. F.A., Abd-El Fattah. Z., (2008). Effect of Chlorella vulgaris as biofertilizer on growth parameters and metabolic aspects of lettuce plant. J Agric Social Sci, 4, 165-169.

Foley. A.J., Ramankutty. N., Braumanak. Cassidy. S.E., Gerber. S.J., Johnston. M., Mueller. D.N., O'connell. C., Ray. K.D., West. C.P., Balzer. C., Bennett. M.E., Carpenter. R.S., Hill. J., Monfreda. C., Polasky. S., Rockstrom. J.,Sheeban. J.. Siebert. S.. Tilman. D.. Zaks. P.D. (2011) Solutions for a cultivated planet. Nature 478, $337-342$.

Górka. B., Korzeniowska. K., Lipok. J.,Wieczorek. P.P., (2018). The Biomass of Algae and Algal Extracts in Agricultural Production. In Algae Biomass: Characteristics and Applications; Springer Science and Business Media LLC: Berlin. Germany. pp. 103-114.

Hallmann. C.A., Foppen. R.P.B., Van Turnhout. C.A.M., De Kroon. H., Jongejans. E. (2014). Declines in insectivorous birds are associated with high neonicotinoid concentrations. Nature511, 341-343.

Hernández-Herrera. R.M.. Santacruz-Ruvalcaba. F.. Ruiz-Lópezma. Norrie. J.. Hernández-Carmona. G. (2013) Effect of liquid seaweed extracts on growth of tomato seedlings (Solanum lycopersicum L.). J Appl Phycol, 26, 619628.

IPCC. (2013). Climate Change 2013: the Physical Science Basis. Contribution of Working Group I to the Fifth Assessment Report of the Intergovernmental Panel on Climate Change. Cambridge University Press. Cambridge. United Kingdom and New York. NY. USA.

Kawalekar. S.J. (2013). Role of biofertilizers and biopesticides for sustainable agriculture. J Biol Innov 2, 73-78.

Köhler. H-R., Triebskorn. R., (2013). Wildlife ecotoxicology of pesticides: can we track effects to the population level and beyond? Science 341, 759-765.

Kumar. G., Sahoo. D., (2011). Effect of seaweed liquid extract on growth and yield of Triticum aestivum var. Pusa Gold. J Appl Phycol, 23, 251-255.

Kumari. R., Kaur. I., Bhatnagar. A.K., (2011). Effect of aqueous extract of Sargassum johnstonii Setchell \& Gardner on growth. yield and quality of Lycopersicon esculentum Mill. J Appl Phycol, 23, 623-633.

Lin. C.S., Chou. T.L., Wu. J.T., (2013). Biodiversity of soil algae in the farmlands of mid-taiwan. Bot Stud. 54:41. DOI: 10.1186/1999-3110-54-41.

Odjadjare. E.C., Mutanda. T., Olaniran. A.O., (2017). Potential biotechnological application of microalgae: a critical review. Crit Rev Biotechnol. 37(1), 37-52. DOI: 10.3109/07388551.2015.1108956. 


\section{Current Trends in Natural Sciences}

Vol. 10, Issue 20, pp. 130-140, 2021

https://doi.org/10.47068/ctns.2021.v10i20.018

Current Trends in Natural Sciences (on-line)

ISSN: 2284-953X

Current Trends in Natural Sciences (CD-Rom)

ISSN: 2284-9521

ISSN-L: 2284-9521

ISSN-L: 2284-9521

Pan. S., Jeevanandam. J., Danquah. M.K., (2019). Benefits of Algal Extracts in Sustainable Agriculture. In Grand Challenges in Marine Biotechnology; Springer Science and Business Media LLC: Berlin. Germany. pp. 501534.

Pathak. J., Rajneesh. Maurya. P.K., Singh S.P., Häder D.P., Sinha R.P., (2018). Cyanobacterial Farming for Environment Friendly Sustainable Agriculture Practices: Innovations and Perspectives. Front. Environ. Sci. 6. $7-$ 19.

Pinheiro. J.C., Bates. D.M., (2000). Extending the basic linear mixed-effects model. In: Mixed Effects Models in S and S-PLUS. Springer-Verlag.

Plaza. C., Schuur. E.A.G., Pegoraro. E.F., (2017a). Eight Mile Lake research watershed. In: Carbon in Permafrost Experimental Heating Research (CiPEHR): Nuclear Magnetic Resonance Spectra of Soils. 2009 and 2013. LTER Bonanza Creek.

Plaza. C., Schuur. E.A.G., Pegoraro. E.F., (2017b). Eight Mile Lake research watershed. In: Carbon in Permafrost Experimental Heating Research (CiPEHR): Physical and Chemical Properties of Soils. 2009-2013. LTER Bonanza Creek.

R Development Core Team, (2015). R: a Language and Environment for Statistical Computing. R Foundation for Statistical Computing. Vienna. Austria.

Sandor. M., (2010). Soil Respiration: Concept and Measurement Methods. ProEnvironment 3, 54 - 57. journals usamvcluj.ro.

Schuur. E.A.G., McGuire. A.D., Schädel. C., Grosse. G., Harden. J.W., Hayes. D.J., Hugelius. G., Koven. C.D., Kuhry. P., Lawrence. D.M., Natali. S.M., Olefeldt. D., Romanovsky. V.E., Schaefer. K., Turetsky. M.R., Treat. C.C., Vonk. J.E., (2015). Climate change and the permafrost carbon feedback. Nature 520, 171-179 doi: 10.0.4.14/ nature 14338.

Sfîrloagă. L.M., Ardelean. I., Diaconu. A., Croitoru. M., (2020). Increasing the chemical parameters of soil andphysiological characteristics of the tomatoes Romec $554 j$ variety by extraradicular treatments with the inoculum of cyanobacteria and microalges. Muzeul Olteniei Craiova. Oltenia. Studii şi comunicări. Ştiinţele Naturii. Tom. 36. No. 1/2020. p. 37-44.

Shaaban. M.M., (2001). Nutritional status and growth of maize plants as affected by green microalgae as soil additives. OnLine J Biol Sci 6, 475-479.

Shaver. G.R.., Canadell. J., Chapin. F.S., Gurevitch. J., Harte. J., Henry. G., Ineson. P., Jonasson. S., Melillo. J., Pitelka. L., Rustad. L., (2000). Global warming and terrestrial ecosystems: a conceptual framework for analysis. BioScience 50. 871-882 doi: 10.1641/0006-3568(2000)050[0871:GWATEA]2.0.CO;2.

Shukla. A.C., Gupta. A.B., (1967). Agriculture: influence of algal growthpromoting substances on growth. yield and protein contents of rice plants. Nature 744.

Soil Survey Staff. (2014). Keys to Soil Taxonomy. 12 ed. USDA-Natural Resources Conservation Service. Washington. DC.

Tarakhovskaya. E.R., Maslov. Y.I., Shishova. M.F., (2007). Phytohormones in algae. Russ J Plant Physiol 54, 163-170

Tilman. D., Cassman. G.K., Matson. A.P., Naylor. R., Polasky. S., (2002). Agricultural sustainability and intensive production practices. Nature 418, 671-677.

Torn. M.S., Southon. J.R., (2001). A new 13C correction for radiocarbon samples from elevated-CO2 experiments. Radiocarbon 43, 691-694.

Tripathi. R.D., Dwivedi. S., Shukla. M.K., Mishra. S., Srivastava. S., Singh. R., (2008). Role of blue green algae biofertilizer in ameliorating the nitrogen demand and fly-ash stress to the growth and yield of rice (Oryza sativa L.) plants. Chemosphere.70, 1919-1928. DOI: 10.1016/j.chemosphere.2007.07.038.

Trumbore. S., (2000). Age of soil organic matter and soil respiration: radiocarbon constraints on belowground C dynamics. Ecological Applications 10. 399-411 10.1890/1051-0761(2000)010[0399:Aosoma]2.0.Co;2.

Trumbore. S.E., Sierra. C.A., Hicks Pries. C.E., (2016a). Radiocarbon nomenclature. theory. models. and interpretation: measuring age. determining cycling rates. and tracing source pools. In: Schuur. E.A.G.. Druffel. E.R.M.. Trumbore. S.E. (Eds.). Radiocarbon and Climate Change. Springer. pp. 45-82.

Trumbore. S.E., Xu. X., Santos. G.M., Czimczik. C.I., Beaupre. S.R., Pack. M.A., Hopkins. F.M., Stills. A., Lupascu. M., Ziolkowski. L., 2016b. Preparation for radiocarbon analysis. In: Schuur. E.A.G.. Druffel. E.R.M.. Trumbore. S.E. (Eds.). Radiocarbon and Climate Change. Springer. pp. 279-308.

Turnbull. J.C., Graven. H., Krakauer. N.Y., 2016. Radiocarbon in the atmosphere. In: Schuur. E.A.G., Druffel. E.R.M., Trumbore. S., (Eds.). Radiocarbon and Climate Change. Springer. pp. 83-138. 


\section{Current Trends in Natural Sciences}

Vol. 10, Issue 20, pp. 130-140, 2021

https://doi.org/10.47068/ctns.2021.v10i20.018

Current Trends in Natural Sciences (on-line)

ISSN: 2284-953X

Current Trends in Natural Sciences (CD-Rom)

ISSN: 2284-9521

ISSN-L: 2284-9521

ISSN-L: 2284-9521

Van der Sluijs. J.P., Amaral-Rogers. V., Belzunces. L.P., Bijleveld Van Lexmond. M.F.I.J., Bonmatin. J.M., Chagnon. M., Wiemers. M., (2014). Conclusions of the worldwide integrated assessment on the risks of neonicotinoids and fipronil to biodiversity and ecosystem functioning. Environ Sci Pollut Res. doi:10.1007/s11356-014-3229-5.

Voicu. M., Coman. V., Enache N., Laslo. L., Matei. M., Rotaru. A., Bara. N., Boboc. M., Stanciu. S., Deak. G., (2020). Experimental Determination of Carbon Dioxide Flux in Soil and Correlation with Dependent Parameters IOP Conf. Ser.: Earth Environ. Sci. 616012010. 